\title{
Active-Brazed Ceramic-Tungsten Carbide Assemblies for Seal Applications
}

\author{
C.A. Walker, J.A. Romero and R.N. Stokes
}

Advanced Prototyping S\&T Department 1832, Sandia National Laboratories*, PO Box 5800 MS0959, Albuquerque, NM 87185-0959

Security seals are used to protect high-value products. High strength and structural integrity during exposure to temperature and humidity extremes are among the design requirements for security seals. For the intended seal application it is critical that the brazed assembly remain crack-free as braided stainless steel cables will be sheared using tungsten carbide (WC) inserts. In the downselect process WC inserts were joined to three types of ceramic substrates using two active brazing filler metals to determine the materials set most likely to survive the intended use environment while minimizing fabrication costs. $\operatorname{MACOR}^{\circledR}[1]$, ninety-four percent alumina ceramic $\left(\mathrm{Al}_{2} \mathrm{O}_{3}\right)$ and zirconia ceramic $\left(\mathrm{Zr}_{2} \mathrm{O}_{3}\right)$ were the ceramic substrates evaluated in this series of brazed samples. Alumina and zirconia are typically machined in the green, or unfired state, to near net shape and subsequently ground using diamond tooling if required. Macor, a glass-ceramic material, is machined in the fired state using standard metalworking tooling. Two commercially available active brazing filler metals having nominal weight percentages $97 \mathrm{Ag}-1 \mathrm{Cu}-2 \mathrm{Zr}$ and $63 \mathrm{Ag}-32 \mathrm{Cu}-2 \mathrm{Ti}$ were used to vacuum furnace braze the ceramic substrates to WC tooling inserts. Active brazing filler metals promote wetting of the ceramic substrate directly, without having to metallize the ceramic surface. Studies have shown [2,3] that similar tensile strength results are obtained whether using metallized ceramic with non-active (standard) or bare ceramic substrates with active brazing filler metals.

Differences in the coefficients of thermal expansion (CTE) for the WC, the ceramic substrate and the braze filler, must be considered in order to fabricate a robust product. It is desirable to have the ceramic member of a metal-ceramic joint remain in compression upon cool-down from the elevated brazing temperature to take advantage of the high compressive strengths of ceramic materials [4]. For brazed assemblies where the ceramic remains in tension, as is the case with this particular material set, it is critical to minimize the residual tensile stresses imposed on the ceramic substrate by utilizing a braze filler metal with favorable yield or creep properties. Additionally, modifying the brazing thermal profile by slowing the cooling rate or adding soak times at elevated temperatures can take advantage of the intrinsic material creep properties to further reduce residual stress. A summary of the results of the initial brazing samples can be seen in Table 1. With the exception of the $\mathrm{Al}_{2} \mathrm{O}_{3} / \mathrm{WC}$ sample brazed using the $97 \mathrm{Ag}-1 \mathrm{Cu}-2 \mathrm{Zr}$ braze filler metal unacceptable cracking or separation of the braze interface was observed. Figures 1 and 2 are SEM images of cross-sections of selected brazements showing favorable (Figure 1a) and unfavorable (Figures 1b, 2a \& 2b) results.

References

[1] MACOR is a registered trademark of Corning Incorporated, Corning, NY 14831.

[2] C.A. Walker et al., Direct Brazing of Sapphire to Niobium, Welding Journal, 89 (3) (2010)

* Sandia is a multiprogram laboratory operated by Sandia Corp., a Lockheed Martin company, for the U.S. Department of Energy under contract DE-AC04-94AL85000. 
[3] C.A. Walker and V.C. Hodges, Comparing Metal-Ceramic Brazing Methods, Welding Journal, 87 (10) (2008)

[4] M.M. Schwartz, Ceramic Joining, ASM International, Materials Park, Ohio 1990

[5] The assistance in sample preparation and analysis by Alice Kilgo and Bonnie McKenzie of Sandia National Laboratories, Albuquerque, NM is gratefully acknowledged.

Table 1. Results of initial brazing samples

\begin{tabular}{|l|l|l|l|}
\hline Sample ID & Substrate 1/Substrate 2 & Braze Filler Metal & Results \\
\hline $071910-2$ & $\mathrm{MACOR}^{\mathbb{B}} / \mathrm{WC}$ & $\mathrm{Ag}-23 \mathrm{Cu}-0.75 \mathrm{Ti}$ & Complete Separation \\
\hline $072210-3$ & $\mathrm{MACOR}^{\mathbb{B}} / \mathrm{WC}$ & $97 \mathrm{Ag}-1 \mathrm{Cu}-2 \mathrm{Zr}$ & Complete Separation \\
\hline $071910-1$ & $94 \% \mathrm{Al}_{2} \mathrm{O}_{3} / \mathrm{WC}$ & $\mathrm{Ag}-23 \mathrm{Cu}-0.75 \mathrm{Ti}$ & Cracking/Separation \\
\hline $072210-1$ & $94 \% \mathrm{Al}_{2} \mathrm{O}_{3} / \mathrm{WC}$ & $97 \mathrm{Ag}-1 \mathrm{Cu}-2 \mathrm{Zr}$ & Crack-free Interfaces \\
\hline $080510-1$ & $\mathrm{Zr}_{2} \mathrm{O}_{3} / \mathrm{WC}$ & $\mathrm{Ag}-23 \mathrm{Cu}-0.75 \mathrm{Ti}$ & Cracking/Separation \\
\hline $080310-1$ & $\mathrm{Zr}_{2} \mathrm{O}_{3} / \mathrm{WC}$ & $97 \mathrm{Wg}-1 \mathrm{Cu}-2 \mathrm{Zr}$ & Cracking/Separation \\
\hline
\end{tabular}

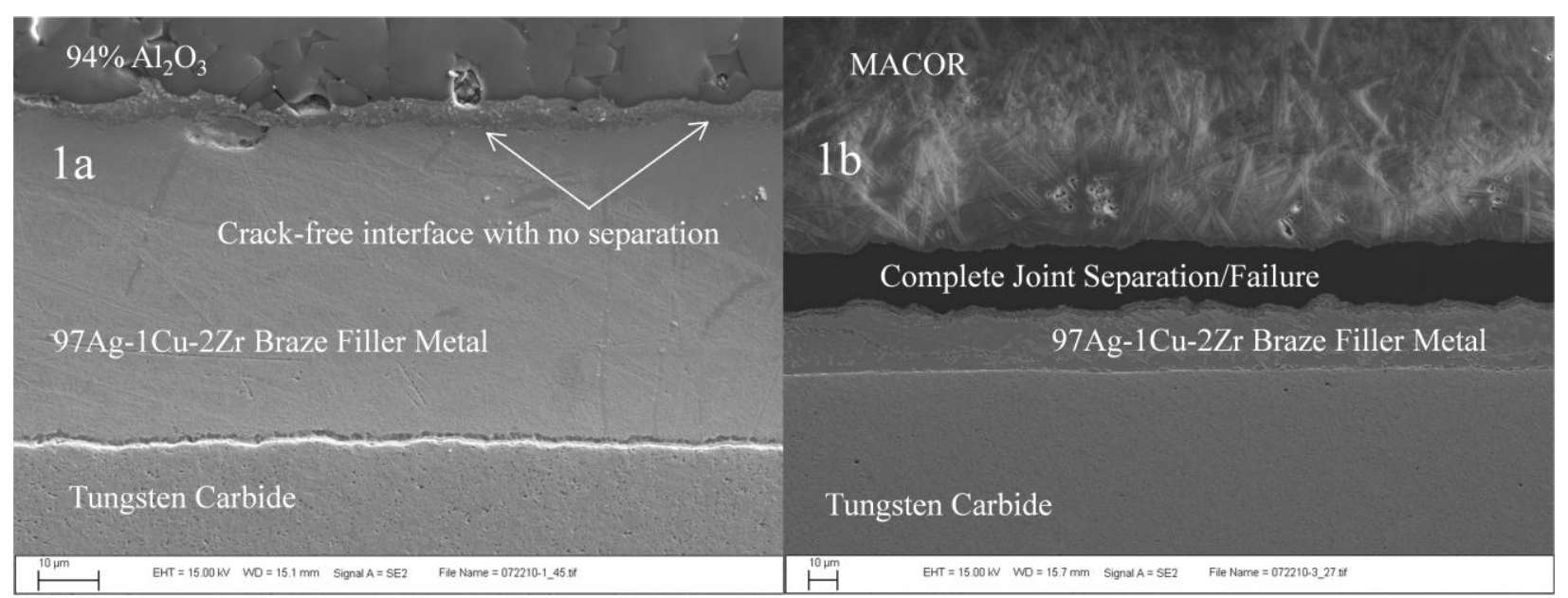

Figure 1. Different results were obtained using different ceramic substrates. Acceptable Joint (1a) made by brazing alumina ceramic to tungsten carbide with $97 \mathrm{Ag}-1 \mathrm{Cu}-2 \mathrm{Zr}$ active brazing filler metal. Total joint failure (1b) observed when brazing MACOR® to tungsten carbide using the same brazing filler metal, $97 \mathrm{Ag}-1 \mathrm{Cu}-2 \mathrm{Zr}$.

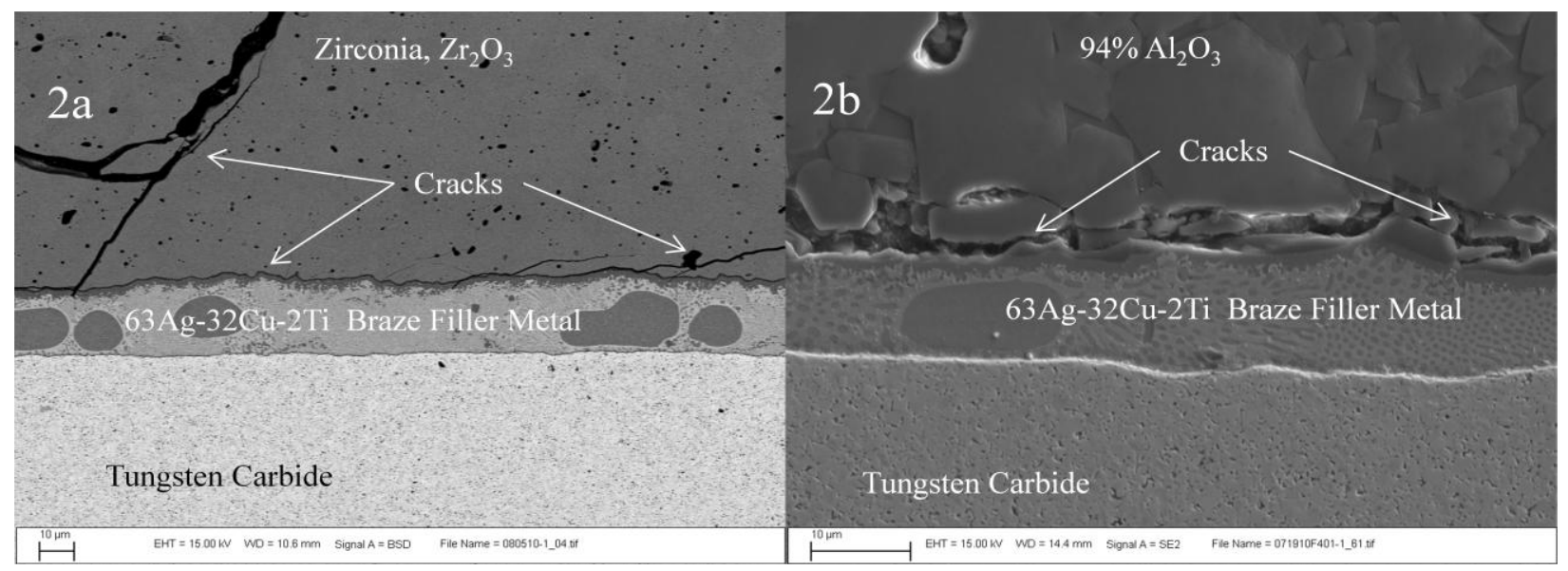

Figure 2. The zirconia (2a) and alumina (2a) ceramic substrates revealed multiple cracks when brazed with the less ductile $63 \mathrm{Ag}-32 \mathrm{Cu}-2 \mathrm{Ti}$ active brazing filler metal. 